\title{
Range extension, new state record and geographic distribution map of Acratosaura mentalis (Amaral, 1933) (Squamata: Gymnophthalmidae)
}

\author{
Michelle de Souza Brito ${ }^{1}$, Luirick Felix Silva Barbosa ${ }^{1}$, Luiz Cezar Machado Pereira ${ }^{1,2}$, Patrícia Avello \\ Nicola $^{1,2}$ and Leonardo Barros Ribeiro ${ }^{1,2 *}$ \\ 1 Centro de Conservação e Manejo de Fauna da Caatinga (CEMAFAUNA-CAATINGA). CEP 56300-990. Petrolina, PE, Brazil. \\ 2 Universidade Federal do Vale do São Francisco (UNIVASF), Campus Ciências Agrárias, Colegiado de Ciências Biológicas. Rodovia BR 407, km 12, \\ Lote 543, s/no - C1. CEP 56300-990. Petrolina, PE, Brazil. \\ * Corresponding author. E-mail: leonardo.ribeiro@univasf.edu.br
}

\begin{abstract}
We provide new records of Acratosaura mentalis from three localities in the state of Pernambuco, Brazil, these records extending the known geographical distribution of the species to the municipalities of Sertânia, Custódia and Floresta. We also report A. mentalis from the municipality of Mauriti, which is the first record for the state of Ceará, Brazil.
\end{abstract}

The gymnophthalmid genus Acratosaura currently comprises two species (Rodrigues et al. 2009): A. mentalis (Amaral, 1933) and A. spinosa Rodrigues, Cassimiro, Freitas and Silva, 2009. Acratosaura mentalis (Figure 1) was described by Amaral (1933) as Colobosaura mentalis based on specimens from the municipality of Vila Nova now Senhor do Bonfim - state of Bahia, Brazil. Colobosaura mentalis was later allocated to the new genus Acratosaura by Rodrigues et al. (2007). The species is cryptic and semifossorial having a large but seemingly insular distribution (Rodrigues 2003; Rodrigues et al. 2007). Acratosaura mentalis is reported from some isolated areas in the Caatingas of northeastern Brazil, and in the Serra do Espinhaço, a large mountain range reaching 2400 $m$ elevation that extends from the state of Minas Gerais to Bahia (Rodrigues et al. 2007). In addition to the type locality, its geographical distribution (based on records available from the literature) currently includes 23 localities in the states of Minas Gerais, Sergipe, Alagoas, Pernambuco, Paraíba and Rio Grande do Norte.

We provide four unpublished localities for $A$. mentalis in northeastern Brazil, three in the state of Pernambuco and one in Ceará (Figure 2), gathered during faunal rescues and monitoring plans for water dams in the framework of the São Francisco river water diversion work (designed to ensure water supply to about 12 million people in 390 municipalities in the states of Pernambuco, Ceará, Paraiba and Rio Grande do Norte, until 2025). Voucher specimens are deposited in the scientific collection of the Centro de Conservação e Manejo de Fauna da Caatinga (CEMAFAUNA-CAATINGA/UNIVASF) (IBAMA collecting permits: $042 / 2007$ and $125 . r / 2010$, Process $n^{\circ}$ 02001.003112/2007-12).

From January 2009 to May 2010, we collected specimens of $A$. mentalis in the state of Pernambuco at the following municipalities: Sertânia (N = 10: LC 449, 563, 1421, 2050, 2107, 2154, 2180, 2528, 2611, 2954; 0804'14" S, 37¹5'57" W; 558 m asl), Custódia (N = 12: LC
43, 44, 66, 204, 719, 797, 909, 976, 1027, 1041, 1111, 1294; $08^{\circ} 05^{\prime} 15^{\prime \prime} \mathrm{S}, 37^{\circ} 38^{\prime} 35^{\prime \prime} \mathrm{W}$; $542 \mathrm{~m}$ asl) and Floresta ( $\mathrm{N}=17$ : LPE 166, 178, 180, 245, 613, 921, 940, 1032, 1048, 1203, 1331, 1333, 1487, 1489, 1500, 1822, 1823; 08³6’04" S, $38^{\circ} 34^{\prime} 07^{\prime \prime} \mathrm{W}$; $316 \mathrm{~m}$ asl). These three collection sites lie in the Caatinga and are characterized by shrub vegetation on a sandy soil. Our new findings of $A$. mentalis in the municipalities of Sertânia, Custódia and Floresta (Figure 3) extend the distribution of this species ca. $60 \mathrm{~km}$ north, $75 \mathrm{~km}$ northwest and $120 \mathrm{~km}$ west, respectively, from the nearest collection site in the municipality of Buíque, state of Pernambuco (Vale do Ipanema; 08³7'24" S, 3709'23” W; $798 \mathrm{~m}$ asl). In Buíque, specimens of $A$. mentalis were collected in the Parque Nacional do Catimbau (Muniz and
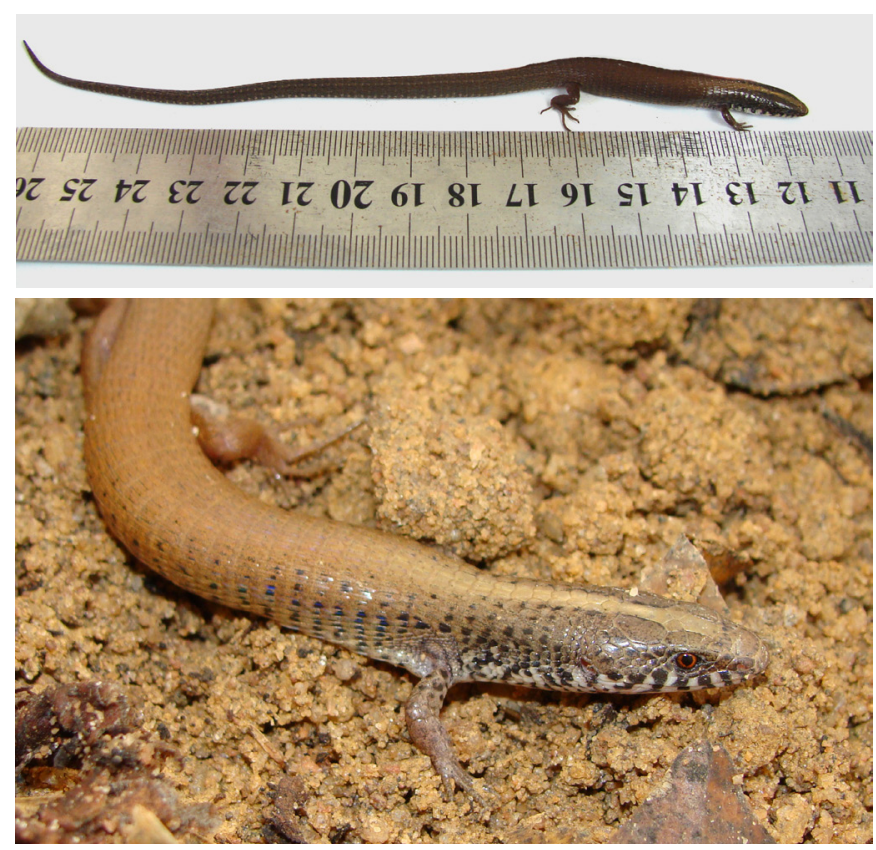

FIGURE 1. Specimen of Acratosaura mentalis (ca. $45 \mathrm{~mm}$ SVL) captured, photographed, and released in the municipality of Floresta, state of Pernambuco, Brazil. Photos (LPE 1786) by CEMAFAUNA-CAATINGA and Melissa Gogliath. 
Santos 2009), where Muniz and Santos (2009) qualified their collection as accidental (less than $25 \%$ of all lizards observed/collected).

On 03 February 2010 in the state of Ceará, an additional adult specimen of $A$. mentalis was collected in the Caatinga in the municipality of Mauriti $\left(07^{\circ} 23^{\prime} 20^{\prime \prime} \mathrm{S}, 38^{\circ} 46^{\prime} 26^{\prime \prime} \mathrm{W}\right.$; $374 \mathrm{~m}$ asl). That specimen was photographed and released at the site of capture (not illustrated because of poor quality of the photograph). To the best of our knowledge, that photograph (catalogued NMA 665) is the first verifiable voucher of the occurrence of $A$. mentalis in the state of Ceará. This extends the geographical distribution of $A$. mentalis ca. $145 \mathrm{~km}$ north from the nearest record in the state of Pernambuco, in the municipality of Floresta (Figure 3). The new records reported here are an important contribution to the knowledge about the distribution and conservation of $A$. mentalis in the Caatinga region of northeastern Brazil.

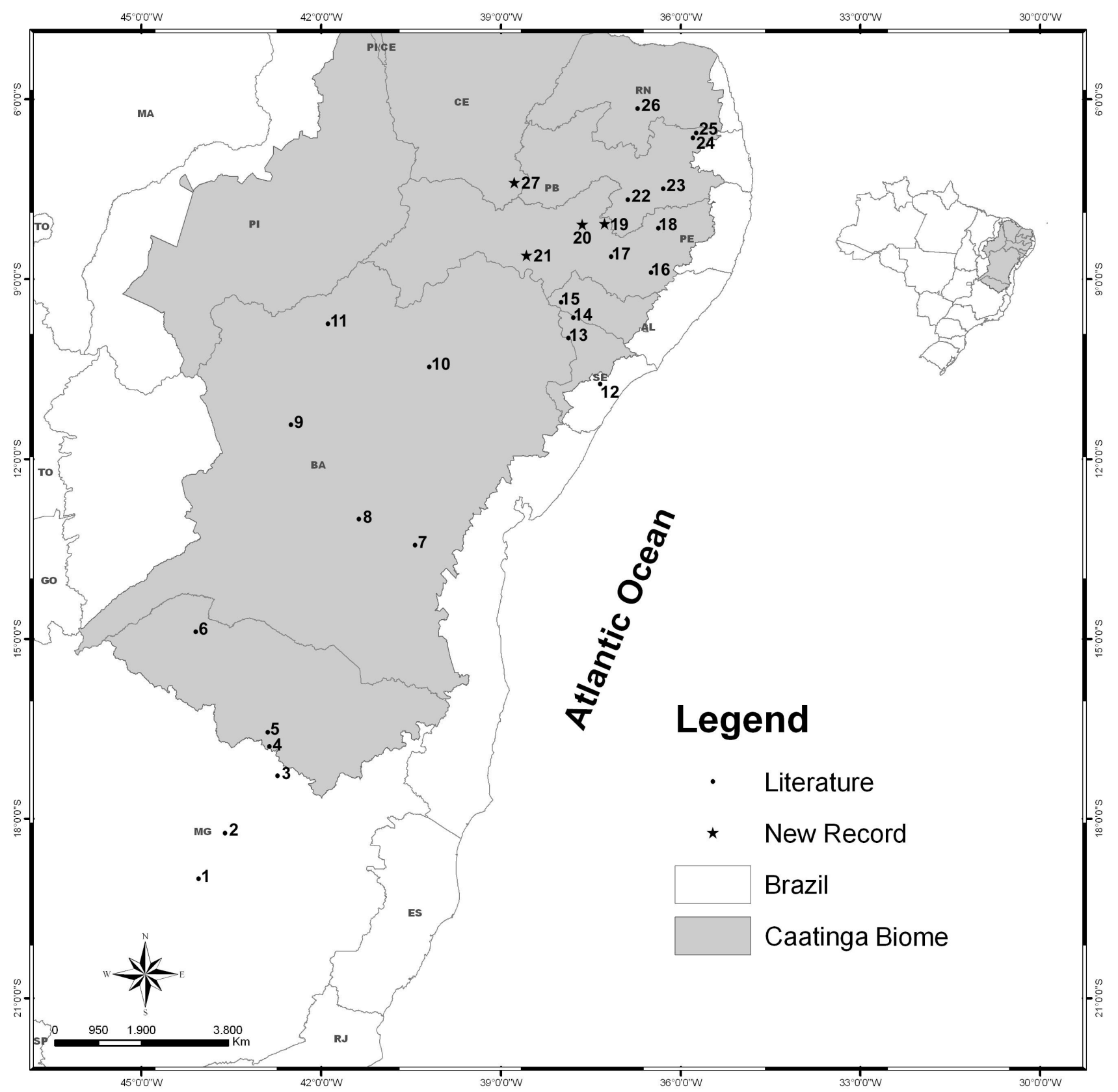

FigURE 2. Geographic distribution of Acratosaura mentalis. Minas Gerais (MG): 1. Santana do Pirapama (Rodrigues et al. 2009), 2. Diamantina (Rodrigues et al. 2009), 3. Turmalina (Rodrigues et al. 2009), 4. Cristália (Rodrigues et al. 2009), 5. Grão Mogol (Rodrigues et al. 2009), 6. Parque Nacional do Peruaçu (Rodrigues et al. 2009); Bahia (BA): 7. Maracás (Rodrigues et al. 2009), 8. Mucugê (MZUSP 74223), 9. Santo Inácio (MZUSP 79743), 10. Senhor do Bonfim (Type-Locality, MZUSP 40084-5), 11. Sento Sé (Santos et al. 2008); Sergipe (SE): 12. Parque Nacional Serra de Itabaiana (De-Carvalho et al. 2010), 13. Serra da Guia (De-Carvalho et al. 2010); Sergipe/Alagoas (AL): 14. UHE Xingó (MZUSP 80182-3); Alagoas (AL): 15. Delmiro Gouveia (Rodrigues et al. 2009); Pernambuco (PE): 16. Garanhuns (MZUSP 65675), 17. Parque Nacional do Catimbau (Rodrigues and Santos 2008), 18. Brejo da Madre de Deus (Queiroz and Lema 1996), 19. Sertânia (New Record), 20. Custódia (New Record), 21. Floresta (New Record); Paraíba (PB): 22. São José dos Cordeiros and Sumé (Freire et al. 2009), 23. Cabaceiras (Rodrigues 1986), 24. Cacimba de Dentro (Arzabe et al. 2005), 25. Parque Estadual Pedra da Boca (Arzabe et al. 2005); Rio Grande do Norte (RN): 26. Tenente Laurentino Cruz (Gogliath et al. 2010) and Ceará (CE): 27. Mauriti (New Record). 


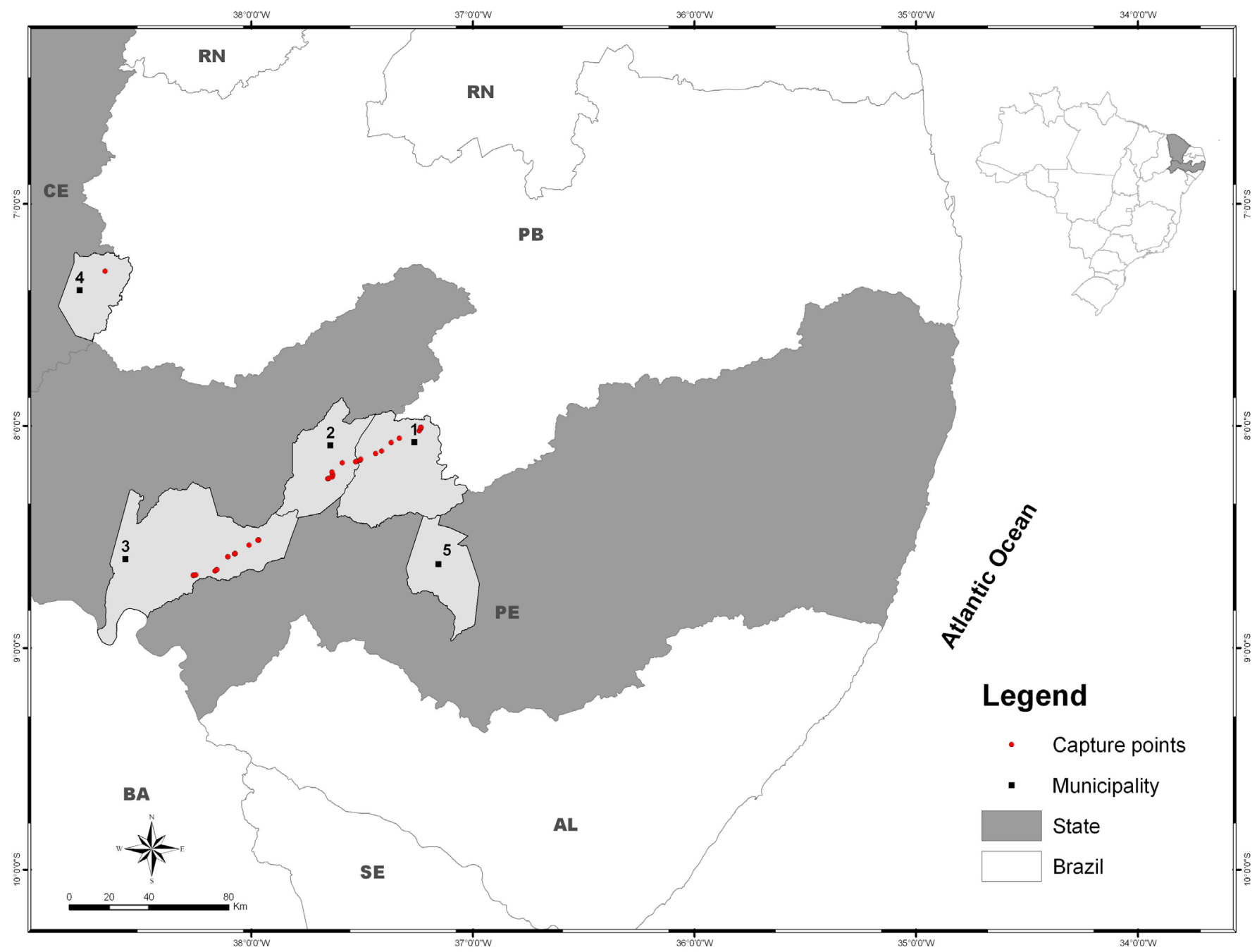

FIGURE 3. Map of northeastern Brazil showing the collection localities of Acratosaura mentalis here published for municipalities from Sertânia (1), Custódia (2) and Floresta (3), state of Pernambuco, and a single record from Mauriti (4), state of Ceará, Brazil. Number 5 represents the previous easternmost distributional record for the species in the municipality of Buíque, state of Pernambuco.

ACKNOWLEDGMENTS: We thank the Ministério da Integração Nacional for financial support, Hussam Zaher for allowing us to use the data about specimens housed in the herpetological collection of Museu de Zoologia da USP. Renato Gomes Faria, Ricardo Arturo Guerra Fuentes, and an anonymous reviewer for providing insightful criticisms on the manuscript.

\section{Literature Cited}

Amaral, A. 1933. Estudos sobre lacertilios neotrópicos. Memórias do Instituto Butantan 7: 1-74.

Arzabe, C., G.O.S. Skuk, G.G. Santana, F.R. Delfim, Y.C.C. Lima and S.H.F. Abrantes. 2005. Herpetofauna da área do Curimataú, Paraíba; p. 264- 280. In F.S. Araújo, M.J.N. Rodal and M.R.V. Barbosa (ed.). Análise das variações da biodiversidade do Bioma Caatinga: suporte a estratégias regionais de conservação. Brasília: Ministério do Meio Ambiente.

De-Carvalho, C.B., F.L.S. Caldas, D.O. Santana, M.V. Noronha, E.B. Freitas, R.G. Faria and R.A. Santos. 2010. Reptilia, Squamata, Gymnophthalmidae, Acratosaura mentalis (Amaral 1933): distribution extension and geographic distribution map. Check List 6(3): 434-436.

Freire, E.M.X., G.O.S. Skuk, M.F. Kolodiuk, L.B. Ribeiro, B.S. Maggi, L.S. Rodrigues, W.L.S. Vieira and A.C.G.P. Falcão. 2009. Répteis das Caatingas do seridó do Rio Grande do Norte e do cariri da Paraíba: síntese do conhecimento atual e perspectivas; p. 51-84 In E.M.X. Freire (org.) Recursos naturais das Caatingas: uma visão multidisciplinar. Natal: Editora Universitária da UFRN.

Gogliath, M., L.B. Ribeiro and E.M.X. Freire. 2010. Acratosaura mentalis (NCN). Geographic distribution. Herpetological Review 41(1): 105106.

Muniz, S.L.S. and E.M. Santos. 2009. Répteis do Vale do Catimbau, Buíque - PE. Jornada de Ensino, Pesquisa e Extensão 9: 1-3.
Queiroz, A.N. and T. Lema. 1996. Novo registro de Colobosaura mentalis Amaral, 1933, (Sauria: Teiidae) para o nordeste do Brasil. Biociências 4(1): 87-90.

Rodrigues, M.T. 1986. Uma nova espécie do gênero Phyllopezus de Cabaceiras: Paraíba: Brasil; com comentários sobre a fauna de lagartos da área (Sauria Gekkonidae). Papéis Avulsos de Zoologia 36(20): 237-250.

Rodrigues, M.T. 2003. Herpetofauna da Caatinga; p. 181-236 In I.R. Leal, M. Tabarelli and J.M.C. Silva (ed.). Ecologia e conservação da Caatinga. Recife: Editora Universitária da UFPE.

Rodrigues, M.T. and E.M. Santos. 2008. A new genus and species of eyelidless and limb reduced gymnophthalmid lizard from northeastern Brazil (Squamata Gymnophthalmidae). Zootaxa 1873: 50-60.

Rodrigues, M.T., J. Cassimiro, M.A. Freitas and T.F.S. Silva. 2009. A new microteiid lizard of genus Acratosaura (Squamata: Gymnophthalmidae) from Serra do Sincorá, State of Bahia, Brasil. Zootaxa 2013: 17-19.

Rodrigues, M.T., K.C.M. Pellegrino, M. Dixo, V.K. Verdade, D. Pavan, A.J.S. Argôlo and J.W. Sites Jr. 2007. A new genus of microteiid lizard from the Atlantic Forests of state of Bahia, Brazil, with a new generic name for Colobosaura mentalis, and a discussion of relationships among the Heterodactylini (Squamata, Gymnophthalmidae). American Museum Novitates 3565: 1-27.

Santos, F.J.M., A.P. Penã and V.L.F. Luz. 2008. Considerações biogeográficas sobre a herpetofauna do Submédio e da Foz do Rio São Francisco, Brasil. Estudos 35(1/2): 59-78.

RECEIVED: August 2011

ACCEPTED: January 2012

PuBlished ONLINE: February 2012

EDITORIAL RESPONSIBILITY: Philippe J. R. Kok 